\title{
Aikuiskasvatus valtion budjetissa ja koulutuskustannukset vapaassa sivistystyössä
}

\section{Aikuiskasvatus valtion budjetissa}

Valtion budjetin yleisperusteluissa on aikuiskoulutuksesta kirjoitettu entistä vähemmän. Perusteluissa todetaan vain lisäykseksi $3 \%$ ja sitten on muutama rivi työllisyyskoulutuksesta ja ammattikursseista.

Oheisiin taulukoihin on koottu opetusministeriön ja aikuiskoulutuksen määrärahojen kehitys viime vuosina. Aikuiskoulutuksen suhteellinen osuus sekä budjetin loppusummasta että
OPM:n pääluokan menoista näyttää alenevan, mutta koska työllisyyskoulutuksen koulutusja erityistuki siirrettiin 1984 työvoimaministeriön hallinnonalalle, niin pieneminen ei ole todellinen.

Kohdassa "muut" on ammatillisen kirjeopetuksen valtionapu 5,8 milj. suurimpana summana. Budjetin mukaan opintokeskuksiin ei voida palkata uutta valtionapuhenkilöstöä. Kansanopistoissa ja kansalais- ja työväenopistoissa voidaan tuntiopetusta muuttaa päätoimiseen opettajien hoidettavaksi opetuksen enimmäismäärän rajoissa.

Taulukko 1. Opetusministeriön hallinnonalan menojen kehitys valtion budjetissa 1982-85

\begin{tabular}{|c|c|c|c|c|}
\hline & $\begin{array}{c}1982 \\
\text { milj.mk }\end{array}$ & $\begin{array}{c}1983 \\
\text { milj.mk }\end{array}$ & $\begin{array}{c}1984 \\
\text { milj.mk }\end{array}$ & $\begin{array}{c}1985 \\
\text { milj.mk }\end{array}$ \\
\hline Budjetin loppusumma & 65000 & 72100 & 84480 & 92927 \\
\hline $\begin{array}{l}\text { — siitä OPM:n pääluokka } \\
\text { — yleissivistävä }\end{array}$ & $17 \%$ & $: 7 \quad \%$ & $16 \%$ & $15,6 \%$ \\
\hline opetus & 4500 & 5000 & 5584 & 5831 \\
\hline - ammattiopetus & 2100 & 2400 & 2739 & 3029 \\
\hline - korkeakouluopetus & 1400 & 1700 & 1790 & 2044 \\
\hline - aikuiskoulutus & 1049 & 1200 & 1083 & 1120 \\
\hline - aikuiskoulutus budjetin & & & & \\
\hline loppusummasta & $1,6 \%$ & $1,7 \%$ & $1,3 \%$ & $1,2 \%$ \\
\hline pääluokasta & $9,5 \%$ & $10 \%$ & $8 \%$ & $7,7 \%$ \\
\hline
\end{tabular}

Taulukko 2. Aikuiskoulutuksen määrärahojen jakaantuminen 1982-85

Ammattikurssit

Yhteiskunnallinen sivistystyö

- kansanopistot

- kansalais- ja työväenopistot

- opintokeskukset

- sivistysjärjestöt

- muut

Yhteensä

\section{Vapaan sivistystyön volyymi}

Viime vuosina on tavallisesti vapaan sivistystyön toiminnan määrästä ilmoitettu osallistujamäärät ja niiden muutokset. Taulukko 3 . opiskelijatilastosta voidaan havaita toiminnan

$\begin{array}{rrrr}\begin{array}{c}1982 \\ \text { milj.mk }\end{array} & \begin{array}{c}1983 \\ \text { milj.mk } \\ 823\end{array} & \begin{array}{c}1984 \\ \text { milj.mk }\end{array} & \begin{array}{c}1985 \\ \text { milj.mk }\end{array} \\ & 842 & 638 & 632 \\ (+273) & (+372) \\ 119 & 141 & 156 & 163 \\ 168 & 200 & 227 & 259 \\ 28 & 38 & 43 & 46 \\ 9 & 10 & 11 & 11 \\ 2 & 2 & 8 & 9 \\ 1049 & 1233 & 1083 & 120\end{array}$

- volyymin pysyneen viimeiset pari - kolme vuotta suunnilleen ennallaan. Pienoista kasvua on tapahtunut. Eniten on kasvanut luentojen kuulijakunta. Kuitenkin vertailtaessa eri organisaatioissa tapahtuvaa opiskelua on muistettava niiden erilaisuus, sillä esim. luento on tavallisesti vain yksittäinen kaksoisluento. 
Taulukko 3. Vapaan sivistystyön opiskelijat 1981-84

Työvuosi

Kansalais- ja työväenopistot

Kansanopistot

- perusoppijaksot

- kurssit

Kalenterivuosi

Opintokeskukset

- kerhot

- kurssit

- ohjaajakoulutus

- luennot
$1981 / 82$

592309

6761

31922

1981

210546

221633

16861

92926
$1982 / 83$

599145

6944

32509

1982

231387

199602

19146

140452
$1983 / 84$

603865

6898

33221

1983

231671

208294

21858

204497

Yhteensä

1172955

1229185

1310404

Vuoden 1983/84 osallistujamäärä noin 1,3 milj. ilmaisee käytännössä opintonsa aloittaneiden kokonaismäärän, mutta ei karsi keskeyttäneitä eikä poista päällekkäisyyttä. Tämä on tietysti puute, mikäli halutaan tietää, moniko kansalainen ylipäätään osallistuu vapaaseen sivistystyöhön.

Osallistujamäärän bruttolukujen mukaan on osallistujia suunnilleen yhtä paljon kansalais- ja työväenopistoissa kuin kaikissa opintokeskuksen työmuodoissa yhteensä ja kansanopistoissa opiskelleiden määrä on huomattavasti alle kahden muun. Tämä 1,3 milj. osallistujaa kuvaa sitä kattavuutta, mikä tällä toiminnalla on yhteiskunnassa verrattuna joihinkin muihin vapaa-ajan käyttömuotoihin. Esim. teatteri- ja oopperalippuja myytiin näytäntökautena 1980/81 noin 2,6 milj., kunnallisissa kirjastoissa oli vuonna 1983 lainaajia kaikkiaan noin 2 milj. ja taidemuseoiden kävijämäärä 1980 oli 1,3 milj.

\section{Valtionapu ja opetustunti}

Valtion ensi vuoden tulo- ja menoarvioesityksestä selviää, paljonko valtinapua on luvas- sa vapaan sivistystyön eri organisaatioille. Kun oletetaan toiminnan volyymin pysyvän suurin piirtein samalla tasolla kuin $1983 / 84$, voidaan laskea suunnilleen, kuinka suuri on yhteiskunnan tuki yhtä opetustuntia kohti vuonna 1985 . Valtiovallan kasvun rajoittamistoimet osaltaan pysyttänevät volyymit suunnilleen nykytasolla.

Opetustunnilla tarkoitetaan yhtä opettajan/ kouluttajan tms. pitämään tuntia. Mittarina tämä on käyttökelpoisempi kuin osallistujamäärä, vaikkakin yhdelle opetustunnille osallistuu erilainen määrä opiskelijoita. Eräissä Pohjoismaissa onkin sivistystyötä tuettu nimenomaan opetustuntikohtaisilla valtionavuilla. Yhteen opetustuntiin kohdistettu valtiontuki voidaan myös melko helposti muuttaa opiskelijatuntiin perustuvaksi arvioksi. Opiskelijatuntia pyrkii esim. UNESCO käyttämään kansainvälisten vertailujensa lähtökohtana.

Kansanopistojen opiskelijamäärät on muutettu opiskelijaviikoiksi, eli yhden opiskelijan viikon (vähintään 30 opetustuntia) kestäväksi opiskeluksi. Opintokerhojen opetusmäärä on saatu kertomalla kerhojen määrä 25942 keskimääräisen yhden opintokerhon tuntimäärällä

Taulukko 4. Vapaan sivistystyön toiminnan volyymi ja valtionapu

$\begin{array}{lccc} & \begin{array}{c}\text { opiskelijaviikkoja } \\ 1983 / 84\end{array} & \begin{array}{c}\text { opetustunteja } \\ 1983 / 84\end{array} & \begin{array}{c}\text { valtionapu 1985 } \\ \text { milj.mk }\end{array} \\ \text { Kansanopistot (89 kpl) } & 264816 & 552862 & 163 \\ & \text { opiskelijoita } & \\ \text { Kansalais- ja työväenopistot } & 1983 / 84 & \\ \text { (278 kpl) } & 603865 & 1877999 & 259 \\ & \text { osallistujia } 1983 & \text { opetust. } 1983 & \\ \text { Opintokeskukset (10 kpl) } & 231671 & 570700 & 7,2 \\ \text { - opintokerho } & 208294 & 119829 & 17,5 \\ \text { - kurssitoiminta } & 21858 & 10012 & 2,2 \\ \text { - ohjaajakoulutus } & 204497 & 7506 & 1,2\end{array}$


(22). Opintokerhotunnit kuitenkin poikkeavat muista opetustunneista perusluonteensa vuoksi siten, että nämä tunnit eivät ole opettajajohtoisia ja kukin kerho saa valtionapua saman summan. Vuonna 1984 tavallinen opintokerho sai valtionapua $260 \mathrm{mk}$ ja laajuutensa ja tasonsa perusteella korotettua valtionapua $(450 \mathrm{mk})$ sai kerhoista noin $15 \%$ (vuoden 1983 tilaston mukaan).

Opetustuntien määrä on viime vuosina tullut tärkeäksi toiminnan volyymin mittariksi, sillä valtiovalta on ryhtynyt sen avulla säätelemään toiminnan kasvua. Kouluhallitus onkin vahvistanut jokaiselle kansalais- ja työväenopistolle valtionapuun oikeuttavien opetustuntien enimmäismäärän. Samalla tavalla on jokaisen opintokeskuksen eri työmuodolle, poissulkien opintokerhot, vahvistettu sekä opetustunti- että markkamääräinen valtionavun katto. Kansanopistojen opetuksen enimmäismäärä säädellään valtionapulakiin perustuvalla opetustuntien ja opiskelijaviikkojen kokonaismäärän suhteella.

Kansalais- ja työväenopistoissa annetaan opetusta noin kolme kertaa enemmän kuin kansanopistoissa tai opintokeskuksissa.

\section{Valtionapu opetustuntia kohti}

Kansanopistojen saama valtionapu yhtä opetustuntia kohti saadaan yksinkertaisella ja- kolaskulla: jaetaan valtionapu (163 milj.mk) opetustuntien kokonaismäärällä. Osamääräksi tulee $294,8 \mathrm{mk}$. On huomattava, että tähän lukuun vaikuttaa opistojen internaattiluonne, eli rakennuksiin ja muun kuin opetushenkilöstön palkkaukseen tuleva valtionapu. Laskelmasta puuttuu opintotukilain perusteella kansanopiston opiskelijoille myönnetty valtion tuki.

Kansanopistojen tuloista on valtionavun osuus keskimäärin $55 \%$ ja opiskelumaksujen $30 \%$ ja loput $15 \%$ kerätään eri lähteistä.

Jakolaskun avulla saadaan kansalais- ja työväenopistojen yhden opetustunnin valtionavuksi $137,9 \mathrm{mk}$. Mutta opistothan ovat 89 prosenttisesti kunnallisia oppilaitoksia, joiden valtionavun ulkopuolelle jäävä osuus katetaan kuntien varoin. Onkin arvioitu, että opistojen tuloista $67 \%$ tulee valtiolta, $30 \%$ kunnilta ja noin 3\% muualta. Suhteutettuna vuoden 1985 valtionapuun saadaan kuntien tueksi noin 61,7 milj. mk, jolloin yhteiskunnan tueksi yhtä opetustuntia kohti tulee 199,7 mk.

Opintokeskusten osalta on yhden opetustunnin valtionavun osuuden laskeminen ongelmallisempaa, sillä keskukset saavat valtionapua ensin yleismenoihinsa ja sitten erikseen kuhunkin työmuotoon. Seuraavassa taulukossa on jaettu opintokeskuksen yleisvaltionapu eri toimintamuotoihin myönnettävän valtionavun määrän suhteessa.

Taulukko 5. Opintokeskusten yleismenojen jako eri toimintamuotoihin

\begin{tabular}{lrrrrr} 
& $\begin{array}{c}\text { valtionapu } \\
\text { toiminta- } \\
\text { muodoille }\end{array}$ & $\%$ & $\begin{array}{c}\text { yleismenoihin } \\
\text { tulevan valt. } \\
\text { avun jako }\end{array}$ & $\begin{array}{c}\text { toiminta- } \\
\text { muodoille } \\
\text { jyvitetty } \\
\text { valtionapu }\end{array}$ \\
Opintokerho & 7250000 & 26 & 4639000 & 11889000 \\
Kurssitoiminta & 17500000 & 62 & 11063300 & 28563300 \\
Ohjaajakoulutus & 2200000 & 8 & 1427500 & 3627500 \\
Luentotoiminta & 1200000 & 4 & 713800 & 1913800 \\
\hline Yhteensä & 28150000 & 100 & 17843600 & $45993600 \mathrm{mk}$ \\
\hline Yleismenot & 17844000 & & & & \\
\hline Valtionapu yht. & $45994000 \mathrm{mk}$ & & & &
\end{tabular}

Kun jyvitetty valtionapu jaetaan taulukossa 2. esitetyillä eri toimintamuotojen opetustuntimäärillä, saadaan että opintokerhotuntia valtio tukee 20,8 , kurssituntia 238,4 , opinto-ohjaajakoulutuksen tuntia 362,3 ja luentotuntia 254,9 markalla. Selvästi kalleimmaksi nousee opinto-ohjaajakoulutus sille myönnettävän valtionavun erityisehtojen vuoksi, sillä valtion- apu mahdollistaa myös opiskelijoiden matkaja majoituskustannusten korvaamisen. Edelleen halvimpana työmuotona on kerhotoiminta.

Opintokeskusten tuloista arvioidaan valtionavun kattavan $74 \%$, opiskelijamaksujen $16 \%$ ja loput tulee hajanaisesti muista lähteistä. 


\section{Yhteenveto}

Joku voisi ehkä laskelmien pohjalta leimata vapaan sivistystyön eräät toimintamuodot tai mahdollisesti koko vapaan sivistystyön liian kalliiksi yhteiskunnalle. Jotta näin voitaisiin väittää, tulisi vapaan sivistystyön menoja verrata esim. kouluopetuksen kuluihin. Valitettavasti tämän kirjoittajalla ei ollut näitä tietoja käytössään. Ehkäpä joku toinen tuntee paremmin tämän koulutusjärjestelmämme osan ja voisi tehdä tällaisen vertailun.

Taulukko 6. Vapaan sivistystyön organisaatioiden saama yhteiskunnan tuki opetustuntia kohti

$\begin{array}{lc}\text { Organisaatio } & \begin{array}{c}\text { tuki } \\ \text { Kk/opetustunti }\end{array} \\ \begin{array}{l}\text { Kansanopisto } \\ \text { Kansalais- ja työväen- } \\ \text { opisto }\end{array} & 295 \\ \begin{array}{l}\text { Opintokeskus } \\ \text { - opinto-ohjaajak. }\end{array} & 200 \\ \text { - luentotunti } & 362 \\ \text { - kurssitunti } & 255 \\ \text { - kerhotunti } & 238 \\ & 21\end{array}$

Mielestäni tämä taulukko joka tapauksessa osoittaa, mihin päädytään kun varsinaisen opetustunnin oheistoimia tuetaan menoperusteisesti, monasti harkinnanvaraisten kriteerien pohjalta. Opettajan saama palkka keskimäärin lienee $80-90 \mathrm{mk}$ tunnilta mahdollisine matkakustannuksineen. Erot eri organisaatioiden välillä ovat mielestäni melko pieniä, kun taas tuntia kohti lasketun valtionavun suuruus yllätti minut.

Lopuksi lainaan varoitukseksi aikuiskoulutuskomitean II osamietintöä sivuilta 35 ja 36 kohdasta "Taloudellinen vaatimus".

- Toiminnan taloudellisuus - käytettyjen resurssien hyötysuhde - on otettava huomi- oon, kun vertaillaan erilaisten organisaatio- ja koulutusmuotojen, työtapojen ja muiden toimintamallien käyttö- ja kehittämismahdollisuuksia. Eri organisaatio- ja koulutusmuotojen käyttömahdollisuuksia vertailtaessa ei päätelmiä kuitenkaan saa tehdä pelkästään jäykästi yhdenmukaisten ja yksinkertaistettujen kustannuskriteerien eikä yleensäkään vain taloudellisuusvertailujen perusteella. On kyettävä arvioimaan myös kunkin organisaatiomuodon erityisluonne ja toimintaedellytykset. Jokin koulutuslohko esim. vaatii kalliimpaa välineistöä kuin toinen. Jollakin työmuodolla taas voi olla sellaisia kasvatuksellisia erityisetuja, joita on vaikea osoittaa täsmällisenä hyötynä.

- Yksipuolinen, kokonaisnäkemyksestä irtautuva taloudellisuuden arviointi johtaa erityisesti kahdenlaisiin harhoihin. Ensinnäkin hyödyn käsitteen tulkitseminen on koulutuksen tuotoksia käsiteltäessä vaikeaa; hyötyä ei pidä käsittää näkyväksi ja tarkasti osoitettavaksi, kvantifioitavaksi aineelliseksi hyödyksi. Toiseksi koulutusta ei pidä arvioida ahtaasti ja yksipuolisesti työvoiman kysynnän perusteella, jolloin kaikki työmarkkinoiden kysynnän tiettynä ajankohtana ylittävä koulutus olisi epätaloudellista.

\section{Lähteet}

Valtion tulo- ja menoarvioesitys 1985. Helsinki 1984.

Tutkimuksia ja selvityksiä 1/1984. Kouluhallitus, Vapaan sivistystyön osasto, Tilastotietoja kansanopistoista, kansalais- ja työväenopistoista ja musiikkioppilaitoksista 1983-1984 sekä opintokeskuksista, urheiluopistoista ja yleisistä kirjastoista vuonna 1983.

Matti Peltonen, Aikuiskoulutuksen kustannukset.

Kulttuuri- ja vapaa-aikatoimen valtionosuustyöryhmän muistio. Helsinki 1984.

Kulttuuritilasto 1981, Tilastokeskus, Tilastollisia tiedonantoja Nro 73. 